PRACE GEOGRAFICZNE

zeszyt 148, 2017, 135-155

doi: 10.4467/20833113PG.17.006.6274

Instytut Geografii i Gospodarki Przestrzennej UJ

Wydawnictwo Uniwersytetu Jagiellońskiego

\title{
OCENA MOŻLIWOŚCI WYKORZYSTANIA SATELITARNYCH DANYCH OPTYCZNYCH I RADAROWYCH DO IDENTYFIKACJI TYPÓW UŻYTKÓW ROLNYCH
}

\author{
Ewa Grabska
}

\section{Assessment of a potential use of satellite optical and radar data for the identification of agriculture land types}

\begin{abstract}
Fusion of satellite data from different sources is a technique commonly used in studies focused on land cover and land use. Combining images of various spectral bands allows to increase objects differentiation and thereby improve overall classification accuracy. In this study, I focused on crops maps creation using integrated optical and radar data. Landsat 8 multispectral data from OLI sensor and Sentinel-1A SAR (Synthetic Aperture Radar) data were applied here. The study was performed for a test area of the Żywiec Basin, which is a part of the Polish Carpathians. The advantage of this small, agricultural region was that it is covered by a mosaic of different-size cultivated fields. I tested six methods of satellite data integration (IHS, HPF, PCA, Brovey, Ehlers and wavelet transforms) and two classification algorithms (Support Vector Machines and Random Forest). The results demonstrated that the use of integrated optical and radar data is effective for crops classification - the highest overall accuracy achieved in this study was equal to $87.9 \%$ and was obtained for Random Forest classification and Ehlers fusion.
\end{abstract}

Keywords: data fusion, image classification, Landsat 8, Sentinel-1A, the Żywiec Basin

Zarys treści: Łączenie danych satelitarnych pochodzących z różnych źródeł jest powszechnie stosowaną techniką w badaniach dotyczących pokrycia terenu i użytkowania ziemi. Łączenie danych o różnych zakresach spektralnych pozwala m.in. na zwiększenie rozróżnialności 
obiektów na powierzchni Ziemi, a tym samym na osiągnięcie wyższej dokładności ich klasyfikacji. Celem opracowania jest ocena możliwości wykorzystania zintegrowanych danych optycznych (obrazy satelitarne pochodzące z satelity Landsat 8, z sensora OLI) i radarowych (obrazy pochodzące z satelity Sentinel-1A) do identyfikacji typów użytków rolnych. Obszarem testowym jest fragment Karpat Polskich - Kotlina Żywiecka, charakteryzująca się występowaniem pól uprawnych o zróżnicowanej wielkości. W artykule przetestowano sześć metod integracji danych satelitarnych (IHS, HPF, PCA, Brovey, Ehlers, transformacje falkowe) oraz dwa algorytmy klasyfikacyjne (wektory maszyn nośnych, ang. Support Vector Machines, SVM i Random Forest). Uzyskane wyniki pozwalają stwierdzić, że wykorzystanie zintegrowanych danych optycznych i radarowych jest efektywnym podejściem w klasyfikacji upraw rolnych najwyższa uzyskana dokładność ogólna wyniosła 87,9\% i została osiągnięta z wykorzystaniem klasyfikacji metodą Random Forest dla danych zintegrowanych przy użyciu techniki Ehlers.

Stowa kluczowe: integracja danych satelitarnych, klasyfikacja obrazów satelitarnych, Landsat 8, Sentinel-1A, Kotlina Żywiecka

\section{Wprowadzenie}

Powierzchnia Ziemi jest obecnie monitorowana przez różnego typu sensory, wykorzystujące zarówno techniki pasywne, jak i aktywne, a obrazy satelitarne są coraz powszechniej dostępne (Joshi i in. 2016; Warner i in. 2009). Jednocześnie dane satelitarne pochodzące $\mathrm{z}$ różnych sensorów, m.in. dane optyczne (np. dane z misji Landsat) i radarowe, najczęściej wykorzystujące techniki SAR (radar z syntetyczną aperturą, Synthetic Aperture Radar; np. Sentinel-1), mogą być integrowane w celu pozyskania informacji o większej dokładności. Łączenie danych satelitarnych pochodzących z różnych źródeł jest obecnie jedną z coraz powszechniej stosowanych technik wykorzystywanych w badaniach pokrycia terenu i użytkowania ziemi (Ban i in. 2015). Podstawowym celem zastosowania takiego podejścia jest osiągnięcie większej ilości informacji niż dla pojedynczego obrazu. Integracja różnych danych może mieć również na celu podwyższenie rozdzielczości przestrzennej obrazu, wzmocnienie rozróżnialności obiektów, zastępowanie brakujących informacji na jednym obrazie informacjami z innego obrazu bądź też detekcję zmian przy użyciu danych z wielu momentów czasowych (Pohl, Genderen 1998). Dane optyczne są rejestrowane najczęściej w zakresach fal widzialnych i podczerwonych, dane radarowe natomiast wykorzystują promieniowanie mikrofalowe (Rosenthal, Blanchard 1984; Roy i in. 2014). Podstawową zaletą danych optycznych jest łatwość ich wizualnej interpretacji, odpowiadają one bowiem najczęściej obrazowi, który widzi ludzkie oko (rejestracja w zakresach widzialnych widma elektromagnetycznego). Główną wadą danych optycznych jest ich zależność od warunków atmosferycznych oraz pory wykonywania zdjęcia (Pohl, Genderen 1998). Dane radarowe natomiast, w przeciwieństwie do danych optycznych, są niewrażliwe na pogodę i czas rejestracji 
- systemy te mają zdolność do przenikania przez chmury i mgłę. Ponadto, obrazy pozyskane w nocy nie różnią się od tych pozyskanych w ciągu dnia. Podstawową wadą danych tego typu jest trudność w ich interpretacji. Co więcej, charakteryzują się one szumami (speckle noise) oraz efektami geometrycznymi (foreshortening, layover, radar shadow; Tso, Mather 1999). Satelitarne dane optyczne i radarowe mogą się więc „uzupełniać” - łączenie danych z różnych obszarów widma elektromagnetycznego często prowadzi do zwiększenia dokładności klasyfikacji - materiały znajdujące się na powierzchni Ziemi w zróżnicowany sposób odbijają, pochłaniają bądź emitują fale elektromagnetyczne. Ponadto dane radarowe mogą uzupełniać luki w danych optycznych, spowodowane np. zachmurzeniem albo zamgleniem (Pohl, Genderen 1998; McNairn i in. 2009; Iannini i in. 2013).

Jednym z typów pokrycia terenu, w którego badaniach często stosowana jest integracja danych optycznych i radarowych, są użytki rolne. W obszarze widma elektromagnetycznego, w którym są rejestrowane obrazy optyczne, odróżnienie upraw i stanu roślin zwykle osiąga się przez szacowanie odbiciowości (reflectance) w kanałach czerwonym i bliskiej podczerwieni. Ilość promieniowania z zakresu widma elektromagnetycznego widzialnego i podczerwonego odbitego przez roślinność jest bezpośrednio związana z pigmentacją roślin, ich wilgotnością oraz wewnętrzną strukturą liści (McNairn i in. 2009). W przypadku danych radarowych, operujących w zakresie mikrofalowym, a zwłaszcza w paśmie C, rozproszenie wsteczne zależy od szorstkości podłoża, wilgotności gleby i gęstości roślinności. Wartości te są również determinowane przez rozmiar, kształt i orientację poszczególnych części rośliny: łodyg, liści oraz owoców. Innymi czynnikami mogą być właściwości dielektryczne roślin oraz ogólny charakter upraw (Moran i in. 2002; McNairn i in. 2009).

Monitorowanie użytków rolnych w czasie okresu wegetacyjnego i szacowanie potencjalnych plonów jest niezwykle ważne m.in. w ocenie produkcji rolnej, a dokładne i aktualne informacje o lokalizacji i powierzchni głównych typów upraw są istotne w różnych działaniach związanych z gospodarką, środowiskiem czy polityką, m.in. służą do zabezpieczenia krótko- i długoterminowego zaopatrzenia w żywność oraz jako mierniki bezpieczeństwa żywnościowego, zarówno w skali lokalnej (Jain i in. 2013), jak i globalnej (Yan, Roy 2014). Aktualne dane na temat upraw są niezbędne m.in. w realizacji zadań dotyczących zaopatrzenia rynku wewnętrznego czy też eksportu (Bochenek i in. 2000). Techniki teledetekcyjne są stosowane do monitoringu użytków rolnych od kilkudziesięciu lat - jednym z podstawowych aspektów satelitarnych badań użytków rolnych jest użycie danych pochodzących z różnych momentów czasowych w jednym roku. Jak wynika z większości badań, wykorzystanie danych wieloletnich jest konieczne do uzyskania dokładnej klasyfikacji większości badanych typów upraw (De Wit, Clevers 2004; Blaes i in. 2005; Iannini i in. 2013). W związku ze zmianami fenologicznymi fizyczne właściwości poszczególnych gatunków roślin mogą się znacznie różnić w kolejnych okresach 
ich wzrostu. Optymalny moment czasowy w badaniach upraw z wykorzystaniem danych teledetekcyjnych jest determinowany przez charakterystyki fenologiczne głównych roślin uprawnych, jak również praktyki rolnicze - żniwa, nawożenie, koszenie (Jewell 1989; Murakami i in. 2001; DeWit, Clevers 2004; Turker, Arikan 2005). W klasyfikacji obrazów radarowych oraz upraw często stosowane jest podejście obiektowe, tzw. per-parcel, gdzie polem podstawowym nie jest pojedynczy piksel, a działka ewidencyjna (Schotten i in. 1995). Przykładami badań, w których do klasyfikacji typów upraw na zintegrowanych obrazach optycznych i radarowych wykorzystano klasyfikację per-parcel, są m.in. prace Bana (1996), DeWita i Cleversa (2004), Iannini i in. (2013) oraz Fourkuora i in. (2014). Z badań tych wynika, że zastosowanie podejścia obiektowego zamiast tradycyjnego pikselowego prowadzi do uzyskania znacznie wyższej dokładności klasyfikacji.

Istnieje wiele różnorodnych technik i metod wykorzystywanych do integracji danych optycznych i radarowych i mimo niewątpliwych zalet stosowania danych teledetekcyjnych z różnych momentów czasowych, w wielu miejscach na świecie, z powodu np. małej powierzchni poszczególnych pól uprawnych, detekcja upraw jest niezwykle trudnym zadaniem (Doraiswamy i in. 2003; Liu 2011). Wiele aspektów prowadzonych badań wpływa na uzyskiwane rezultaty, dlatego w osiągnięciu satysfakcjonujących wyników jest konieczne dokładne przestudiowanie metod stosowanych na każdym etapie przetworzeń. Celem tych badań jest ocena możliwości wykorzystania zintegrowanych danych optycznych (obrazy satelitarne pochodzące z satelity Landsat 8, z sensora OLI) i radarowych (obrazy pochodzące z satelity Sentinel-1A) do identyfikacji typów użytków rolnych. Oceniono możliwość wykorzystania danych średniorozdzielczych w klasyfikacji upraw na specyficznym obszarze o bardzo zróżnicowanej wielkości pól uprawnych, z przewagą pól małych i bardzo małych. W tym artykule oceniono również, która z testowanych metod integracji danych optycznych i radarowych pozwala na uzyskanie największej dokładności klasyfikacji upraw - wybór techniki integracji jest często pomijany w pracach dotyczących klasyfikacji upraw na zintegrowanych danych satelitarnych. Kolejnym aspektem podjętym w opracowaniu było określenie, jak na otrzymane wyniki wpływa wybór algorytmu klasyfikacyjnego.

\section{Obszar testowy}

Na obszar testowy wybrano fragment Kotliny Żywieckiej o powierzchni $186 \mathrm{~km}^{2}$ (ryc. 1). Czynnikiem decydującym o wyborze obszaru był jego typowo rolniczy charakter oraz występowanie mozaiki pól uprawnych o zróżnicowanej wielkości (od 0,01 ha do 36 ha), z przewagą pól małych i bardzo małych. Klimat Kotliny Żywieckiej charakteryzuje się długim okresem przymrozkowym (Balon i in. 1995). Średnia roczna temperatura wynosi od $6^{\circ} \mathrm{C}$ do $8^{\circ} \mathrm{C}$ (Obrębska-Starklowa i in. 


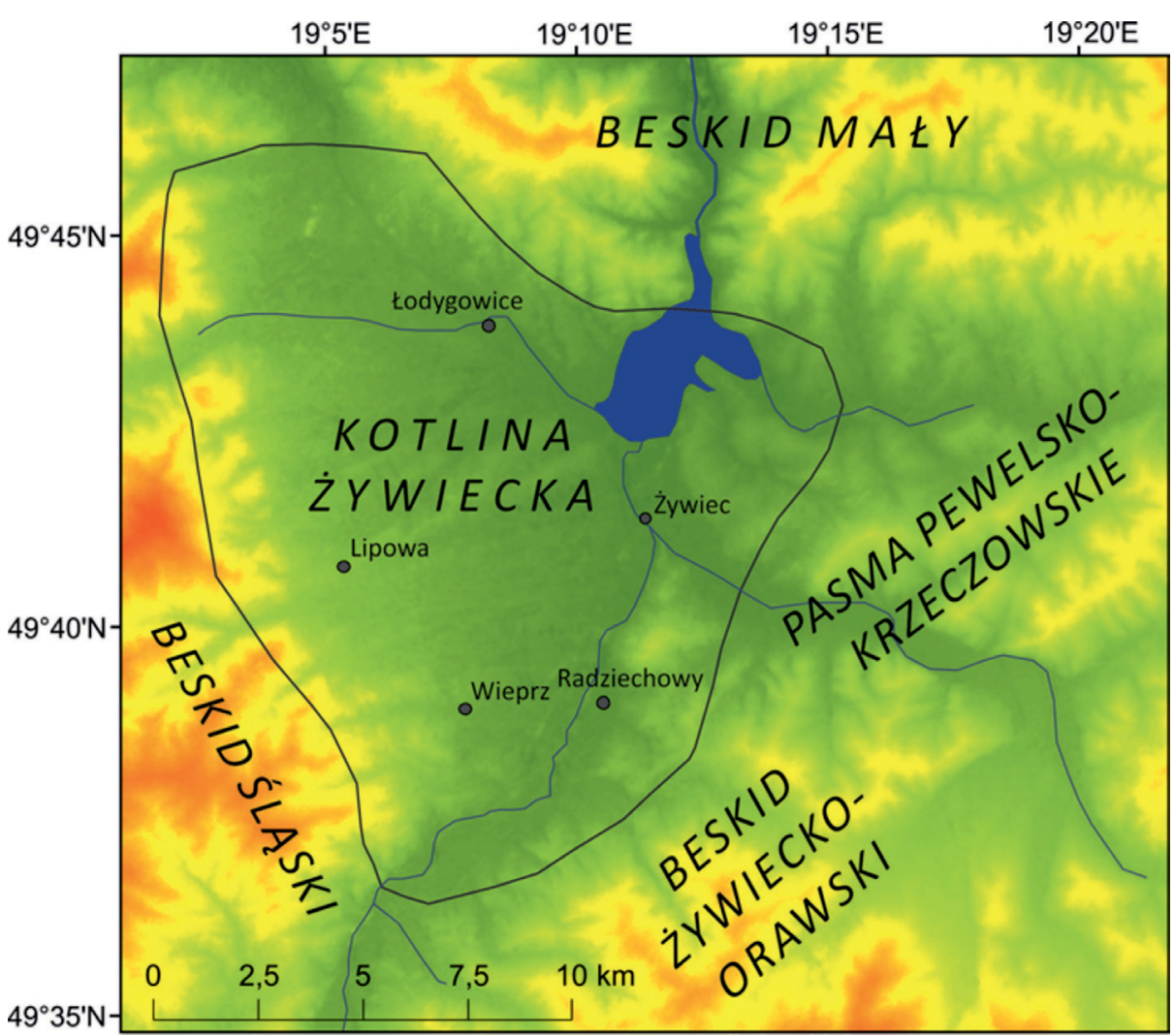

Ryc. 1. Obszar badań - Kotlina Żywiecka

Fig. 1. Study area - the $\dot{Z}$ ywiec Basin

1995). Ponadto Kotlina Żywiecka jest obszarem występowania cienia opadowego, w związku z czym roczne sumy opadów na jej obszarze są niższe niż w sąsiadujących regionach i wynoszą średnio mniej niż 1000 mm (Leśniak, Obrębska-Starklowa 1983). Mimo niekorzystnego klimatu morfologia obszaru stwarza warunki sprzyjające rolnictwu. Występują tutaj gleby płowe (Skiba 1995). Środowisko przyrodnicze Kotliny Żywieckiej jest bardzo przekształcone przez człowieka, a region jest obecnie niemal całkowicie wylesiony (Kondracki 1998). Obszar testowy pod względem uprawianych roślin jest umiarkowanie zróżnicowany. Według Powszechnego Spisu Rolnego przeprowadzonego w 2010 r. pola uprawne na badanym obszarze zajmowały powierzchnię 1462 ha. Większość zasiewów stanowiły różnego rodzaju zboża, których powierzchnia ogółem wynosiła 833 ha, oraz ziemniaki zajmujące powierzchnię 
248 ha. Oprócz zbóż i ziemniaków dużą powierzchnię zajmowały uprawy roślin przemysłowych zlokalizowane głównie w gminie Lipowa (ogółem 182 ha). Innymi uprawianymi roślinami były buraki cukrowe oraz warzywa gruntowe. Wśród zbóż najczęściej zasiewana była pszenica ozima (312 ha) oraz owies (184 ha), najrzadziej zaś mieszanki zbożowe ozime (2 ha) oraz żyto ( 8 ha).

\section{Dane}

W toku postępowania wykorzystano obrazy optyczne pozyskane przez satelitę Landsat 8, sensor OLI (Operational Land Imager) oraz dane radarowe pochodzace z satelity Sentinel-1A wyposażonego w radar z syntetyczną aperturą (SAR). Dane te zostały wybrane ze względu na dostępność, zadowalającą rozdzielczość przestrzenną oraz aktualność. Obrazy satelitarne Landsat OLI zostały pozyskane z serwisu http://earthexplorer.usgs.gov/. Pobrano dane po korekcji radiometrycznej metodą LEDAPS (Landsat Ecosystem Disturbance Adaptive Processing System) z zapisanymi wartościami odbiciowości (reflectance) dla 7 czerwca 2014 r. Pozyskane obrazy OLI po korekcji składały się z siedmiu kanałów w zakresach fal widzialnych i podczerwonych o rozdzielczości przestrzennej wynoszącej 30 metrów (Maiersperger i in. 2013; Roy i in. 2014). Dane radarowe Sentinel-1A wykorzystane w pracy zostały pozyskane w trybie Interferometric wide-swath (IW). Rozdzielczość azymutalna dla danych IW wynosiła $20 \mathrm{~m}$, natomiast terenowa rozdzielczość odległościowa (Ground Range Resolution ) - 5 m. W badaniach zastosowano produkty GRD (Ground Range Detected) o rozdzielczości przestrzennej $10 \mathrm{~m}$. Użyto obrazów w dwóch rodzajach polaryzacji (VV oraz VH), pozyskanych dla 2 sierpnia 2014 r. (Sentinel-1 Product Definition 2011). Dane radarowe Sentinel-1A zostały pozyskane dzięki uprzejmości dra Chrisa Stewarta (ESA) oraz pracowników PDGS (Payload Data Ground Segment). Oprócz obrazów satelitarnych w pracy zostały użyte także dane treningowe i referencyjne wygenerowane dla dwóch poziomów klasyfikacji pokrycia terenu. Na pierwszym poziomie klasyfikacji wykorzystano dane pozyskane dzięki wizualnej interpretacji obrazu OLI oraz obrazów o bardzo wysokiej rozdzielczości przestrzennej udostępnianych w aplikacji GoogleEarth. Źródłem informacji o typach upraw rolnych występujących na obszarze testowym były natomiast badania terenowe, podczas których przeprowadzono wywiady z właścicielami i pracownikami gospodarstw rolnych, dotyczące roślin uprawianych na poszczególnych polach w 2014 r. Dane pochodzące z wywiadów naniesiono następnie na ortofotomapy z lat 2013-2014. W przypadku większych pól, zlokalizowanych m.in. w Gospodarstwie Hodowli Zarodowej w Wieprzu, wylosowano punkty wewnątrz pól uprawnych porośniętych przez jeden typ roślin uprawnych. Ten sam proces został zastosowany przy tworzeniu warstwy do weryfikacji. 


\section{Metody}

W badaniach zajmowano się klasyfikacją zintegrowanych obrazów optycznych i radarowych pod kątem typów upraw rolnych. Sklasyfikowanych zostało 10 typów upraw: trawa, pszenica, kukurydza, lucerna, jęczmień, rzepak, ziemniaki, owies, pszenżyto i koniczyna. Przed przeprowadzeniem klasyfikacji koniecznym etapem była filtracja szumów dla danych radarowych. Kolejnym krokiem była integracja przetworzonych danych za pomocą sześciu metod: IHS, HPF, PCA, Brovey, Ehlers oraz transformacji falkowej. Następnie przeprowadzono dwuetapową klasyfikację nadzorowaną, w której wykorzystano dwa algorytmy parametryczne: maszyny wektorów nośnych (SVM, Support Vector Machines) oraz klasyfikator Random Forest. W pierwszym etapie sklasyfikowane zostały cztery klasy pokrycia terenu: obszary użytkowane rolniczo, obszary zabudowane, lasy i wody. W drugim etapie sklasyfikowanych zostało 10 wymienionych wyżej typów upraw. Ostatnim etapem przetworzeń była ocena dokładności otrzymanych map (ryc. 2).

$\mathrm{W}$ przypadku danych radarowych pierwszym etapem przetworzeń była filtracja szumów, czyli efektu plamkowania. W badaniach zastosowano filtrację metodą Gamma-MAP (The Maximum A Posteriori) o oknie filtrującym 3x3 (Wang i in. 2012).

Ryc. 2. Ścieżka postępowania Fig. 2. Workflow

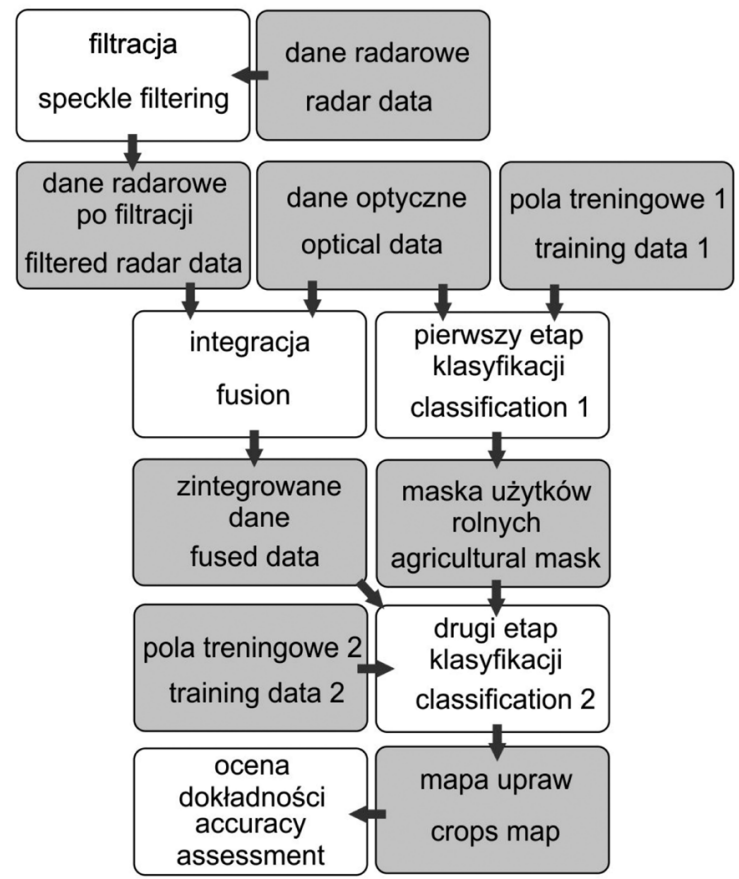


Następnie przetworzone i przycięte do obszaru testowego obrazy satelitarne OLI i Sentinel-1A w dwóch polaryzacjach ( VV i VH) zostały poddane integracji na poziomie pikselowym z wykorzystaniem sześciu technik: IHS, HPF, PCA, Brovey, Ehlers oraz transformacji falkowej (Pohl, Genderen 1998; Klonus, Ehlers 2009; Sarup, Singhai 2011). W przypadku integracji PCA, HPF, Brovey, Ehlers i transformacji falkowej wykorzystano wszystkie siedem kanałów obrazu optycznego, w przypadku zaś integracji metodą IHS - kanały 4. (widzialny czerwony), 5. (bliskiej podczerwieni) oraz 6. (krótkofalowej podczerwieni), ponieważ w badaniach dotyczących upraw zazwyczaj stosuje się wartości odbiciowości dla tych właśnie zakresów fali elektromagnetycznej. Zintegrowane obrazy poddano ocenie wizualnej, w której zwrócono uwagę na zachowanie właściwości spektralnych, teksturalnych oraz kształtów w stosunku do oryginalnego obrazu OLI. Po ocenie wizualnej do dalszych analiz wybrano obrazy zintegrowane metodami IHS, PCA, Brovey oraz Ehlers. Powyższe transformacje zostały przeprowadzone w oprogramowaniu ERDAS Desktop 2013.

Do identyfikacji upraw wybrano automatyczną metodę klasyfikacji hierarchicznej - dane optyczne i radarowe zostały poddane dwuetapowej klasyfikacji nadzorowanej. W pierwszym etapie klasyfikacji, w którym wykorzystano wyłącznie dane optyczne, sklasyfikowane zostały cztery klasy pokrycia terenu: obszary użytkowane rolniczo, obszary zabudowane, lasy oraz wody. Zastosowano jeden z najczęściej stosowanych w tego typu klasyfikacjach algorytm maszyn wektorów nośnych (Huang i in. 2002), oparty na statystycznej teorii uczenia (Cortes, Vapnik 1995). Otrzymana w procesie klasyfikacji maska użytków rolnych została zastosowana w drugim etapie klasyfikacji, przeprowadzonej na zintegrowanych danych optycznych i radarowych. W klasyfikacji upraw zdecydowano się wykorzystać dwa różne algorytmy nieparametryczne: SVM oraz Random Forest. Algorytm Random Forest jest techniką uczenia maszynowego wywodzącą się z predykcyjnego modelu drzew decyzyjnych, wykorzystującego zestaw reguł binarnych (Horning 2010). Przeprowadzona w pracy klasyfikacja metodą SVM została wykonana w oprogramowaniu ENVI 5.2.1. Po przetestowaniu zmian parametrów dostępnych przy klasyfikacji metodą SVM zdecydowano się na pozostawienie parametrów domyślnych (Kernel Type: Radial Basis Function, Gamma in Kernel Function: 0,125, Penalty Parameter: 100, Pyramid Levels: 0, Classification Probability Threshold: 0,00). Klasyfikacja metodą Random Forest została natomiast przeprowadzona w darmowym oprogramowaniu EnMAP-Box 2.1 (http:// www.enmap.org). Przed wykonaniem klasyfikacji konieczna była parametryzacja algorytmu klasyfikacyjnego. Liczba drzew została ustalona na 100. Łącznie w procesie klasyfikacji wykorzystano 138 punktów treningowych w pierwszym etapie klasyfikacji oraz 186 punktów treningowych w etapie drugim. Uzyskane w procesie klasyfikacji mapy wyjściowe zostały następnie poddane ocenie dokładności. Oprócz map upraw utworzonych na podstawie zintegrowanych danych optycznych i radarowych klasyfikację obiema metodami przeprowadzono również tylko dla danych OLI. Ocena 
dokładności obejmowała obliczenie powszechnie stosowanych wskaźników: macierzy błędów, dokładności ogólnej, dokładności producenta, dokładności użytkownika i współczynnika Kappa. W ocenie dokładności dla pierwszego etapu klasyfikacji wykorzystano 141 punktów, a dla drugiego etapu - 165 punktów. Dla obu etapów klasyfikacji punkty zostały wybrane na podstawie wizualnej interpretacji zdjęcia.

\section{Wyniki}

W rezultacie integracji danych optycznych i radarowych czterema różnymi metodami (Ehlers, Brovey, PCA, IHS) uzyskano osiem nowych, zintegrowanych obrazów wyjściowych, charakteryzujących się odmiennymi właściwościami spektralnymi i teksturalnymi (ryc. 3). W pierwszym etapie klasyfikacji metodą SVM otrzymano mapę pokrycia terenu obejmującą cztery klasy: użytki rolne, obszary zabudowane, lasy oraz wody. Największą powierzchnię zajmują na obszarze badań użytki rolne $\left(118 \mathrm{~km}^{2}\right)$, kolejnymi klasami są: lasy $\left(52 \mathrm{~km}^{2}\right)$, obszary zabudowane $\left(9 \mathrm{~km}^{2}\right)$ oraz wody $\left(7 \mathrm{~km}^{2}\right)$. W drugim etapie klasyfikacji, w którym wykorzystano zintegrowane dane optyczne i radarowe, otrzymano 15 wyjściowych map upraw (ryc. 4, 5).

Na podstawie wizualnej interpretacji otrzymanych map, są widoczne znaczne różnice w otrzymanych wynikach. W porównaniu z metodą Random Forest w wyniku klasyfikacji z wykorzystaniem algorytmu SVM niektóre z klas upraw występujących na obszarze testowym zostały całkowicie pominięte (niesklasyfikowane). Były to głównie uprawy o mniejszej próbie danych treningowych - m.in. ziemniaki oraz jęczmień. Wizualna interpretacja pozwoliła stwierdzić, że wyższą ogólną dokładność uzyskano w przypadku użycia algorytmu Random Forest. Widoczne były także różnice w klasyfikacji w zależności od użytej metody integracji. W przypadku integracji metodami Ehlers oraz PCA, granice sklasyfikowanych pól były wyraźnie bardziej „wygładzone” w stosunku do integracji metodą Brovey, co można zaobserwować zwłaszcza w przypadku większych pól. Na wszystkich wygenerowanych mapach dominującą klasą była trawa, do innych, licznie reprezentowanych klas upraw należały: owies, pszenica oraz koniczyna. W klasyfikacji metodą SVM dysproporcje pomiędzy poszczególnymi klasami były znacznie większe. Najmniejszymi powierzchniowo klasami na badanym obszarze były uprawy jęczmienia, pszenżyta oraz lucerny.

W pierwszym etapie klasyfikacji dokładność ogólna wyniosła 97,9\%, a współczynnik Kappa - 97\%. Z największą dokładnością sklasyfikowane zostały wody, z najmniejszą zaś obszary zabudowane (tab. 1).

W drugim etapie przetworzeń najwyższa dokładność klasyfikacji została osiągnięta przy klasyfikacji metodą Random Forest dla danych zintegrowanych metodą Ehlers przy polaryzacji VV danych radarowych. Dokładność ogólna dla powyższych parametrów wyniosła 87,9\%, a współczynnik Kappa 86\% (tab. 2, 3). Dokładność 

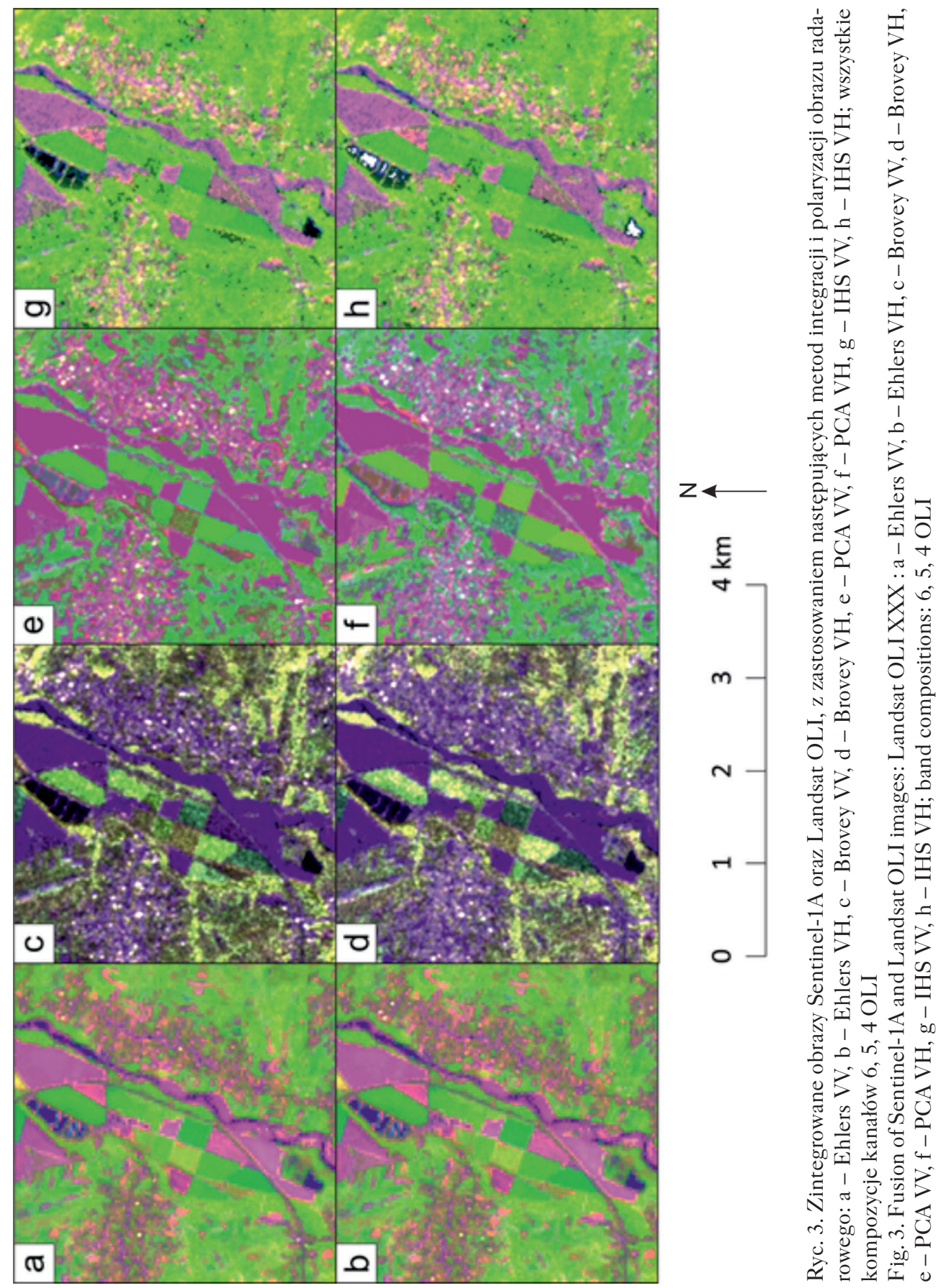

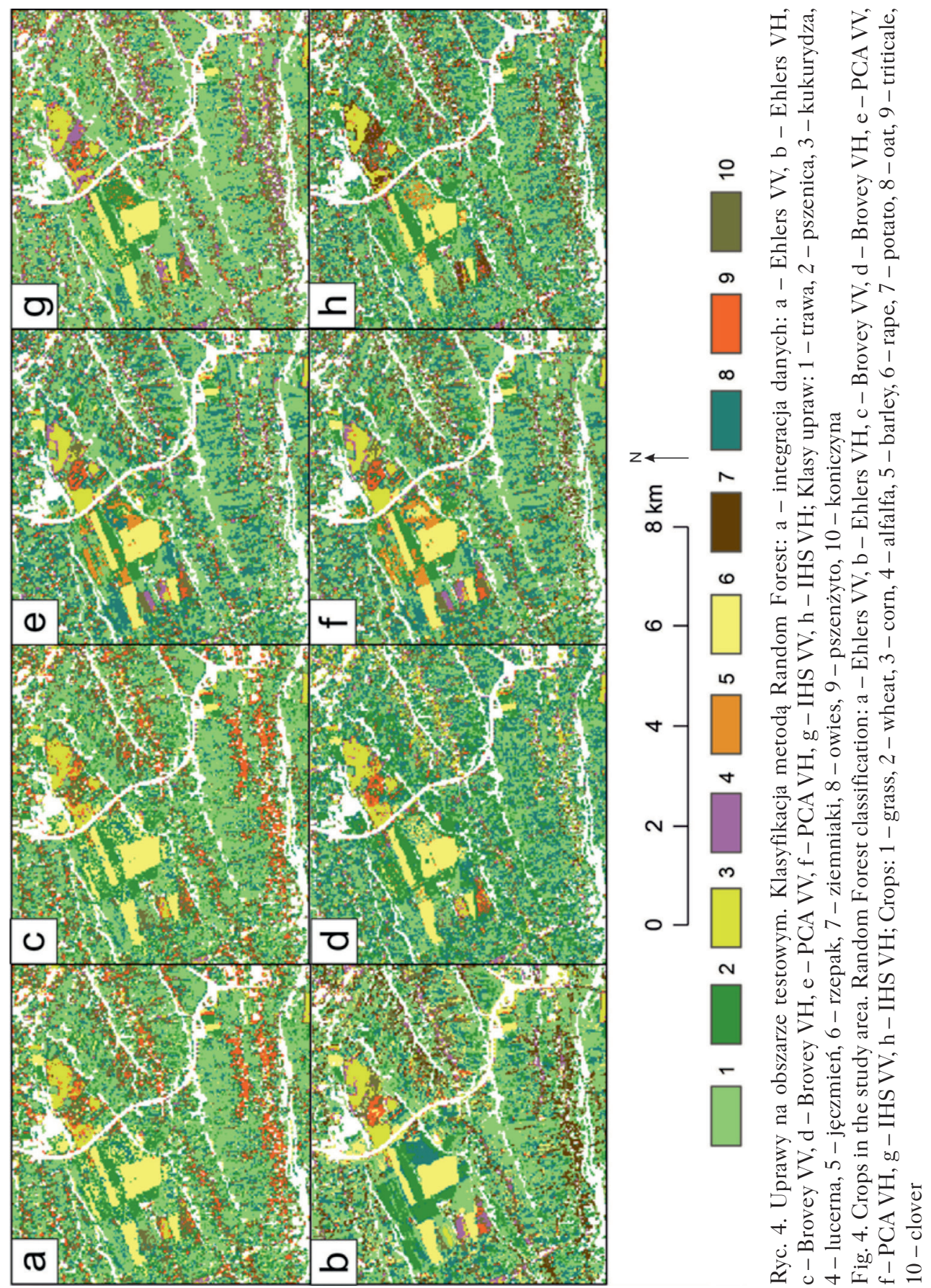

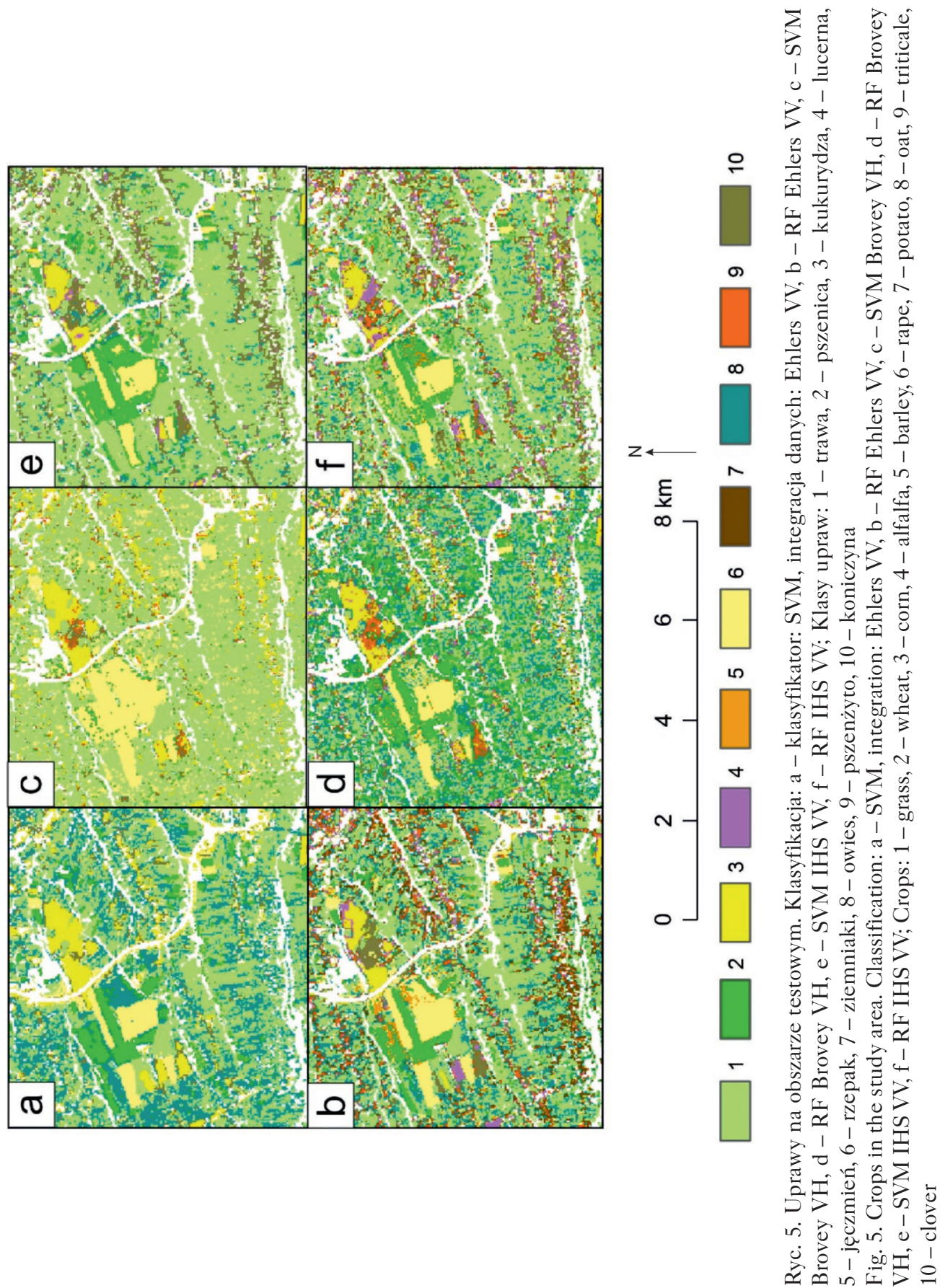
Tab. 1. Macierz błędów - pierwszy etap klasyfikacji; 1 - wody; 2 - obszary zabudowane; 3 - użytki rolne; 4 - lasy

Table 1. Confusion matrix - first step of classification; 1 - water bodies; 2 - built-up areas; 3 - agricultural areas; 4 - forests

\begin{tabular}{|c|c|c|c|c|c|c|}
\hline & \multicolumn{5}{|c|}{ Dane referencyjne / Reference Data } \\
\hline & & 1 & 2 & 3 & 4 & $\begin{array}{l}\text { suma } \\
\text { sum }\end{array}$ \\
\hline \multirow{7}{*}{ 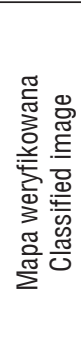 } & 1 & 25 & 0 & 0 & 0 & 25 \\
\hline & 2 & 0 & 29 & 1 & 0 & 30 \\
\hline & 3 & 0 & 1 & 49 & 1 & 51 \\
\hline & 4 & 0 & 0 & 0 & 35 & 35 \\
\hline & suma / sum & 25 & 30 & 50 & 36 & 141 \\
\hline & $\begin{array}{c}\text { dokł. użyt. } \\
\text { user's acc. [\%] }\end{array}$ & 100 & 96,7 & 96,1 & 97,2 & \\
\hline & $\begin{array}{c}\text { dokł. prod. } \\
\text { producer's acc. [\%] }\end{array}$ & 100 & 96,7 & 98,0 & 100 & \\
\hline
\end{tabular}

Tab. 2. Ocena dokładności klasyfikacji zintegrowanych danych satelitarnych

Table 2. Classification of fused data accuracy assessment

\begin{tabular}{|c|c|c|c|c|}
\hline \multicolumn{3}{|c|}{$\begin{array}{l}\text { Dane wejściowe } \\
\text { Input data }\end{array}$} & \multirow{2}{*}{$\begin{array}{c}\text { Dokładność ogólna } \\
\text { Overall Accuracy } \\
{[\%]}\end{array}$} & \multirow{2}{*}{$\begin{array}{c}\text { Współ. Kappa } \\
\text { Kappa } \\
\text { Coefficient } \\
{[\%]}\end{array}$} \\
\hline $\begin{array}{c}\text { Klasyfikacja } \\
\text { Classification }\end{array}$ & $\begin{array}{l}\text { integracja } \\
\text { fusion }\end{array}$ & $\begin{array}{l}\text { polaryzacja } \\
\text { polarization }\end{array}$ & & \\
\hline \multirow{8}{*}{ Random Forest } & \multirow{2}{*}{ Ehlers } & VV & 87,9 & 86,0 \\
\hline & & $\mathrm{VH}$ & 84,9 & 82,4 \\
\hline & \multirow{2}{*}{ Brovey } & VV & 80,0 & 76,7 \\
\hline & & $\mathrm{VH}$ & 72,7 & 68,3 \\
\hline & \multirow{2}{*}{ PCA } & VV & 81,2 & 78,3 \\
\hline & & $\mathrm{VH}$ & 81,2 & 78,3 \\
\hline & \multirow{2}{*}{ IHS } & VV & 79,4 & 76,1 \\
\hline & & $\mathrm{VH}$ & 76,4 & 72,5 \\
\hline \multirow{8}{*}{ SVM } & \multirow{2}{*}{ Ehlers } & VV & 63,6 & 57,0 \\
\hline & & $\mathrm{VH}$ & - & - \\
\hline & \multirow{2}{*}{ Brovey } & VV & 51,5 & 42,2 \\
\hline & & $\mathrm{VH}$ & 52,1 & 41,9 \\
\hline & \multirow{2}{*}{ PCA } & VV & 67,9 & 62,1 \\
\hline & & $\mathrm{VH}$ & 67,9 & 62,1 \\
\hline & \multirow{2}{*}{ IHS } & VV & 69,7 & 64,2 \\
\hline & & $\mathrm{VH}$ & 61,8 & 55,0 \\
\hline
\end{tabular}


Tab. 3. Macierz błędów - klasyfikacja Random Forest, integracja Ehlers, polaryzacja VV; 1 - trawa, 2 - pszenica, 3 - kukurydza, 4 - lucerna, 5 - jęczmień, 6 - rzepak, 7 - ziemniaki, 8 - owies, 9 -pszenżyto, 10 - koniczyna

Table 3. Confusion matrix - Random Forest Classification, Ehlers integration, VV polarization; 1 - grass, 2 - wheat, 3 - corn, 4 - alfalfa, 5 - barley, 6 - rape, 7 - potato, 8 - oat, 9 - triticale, 10 - clover

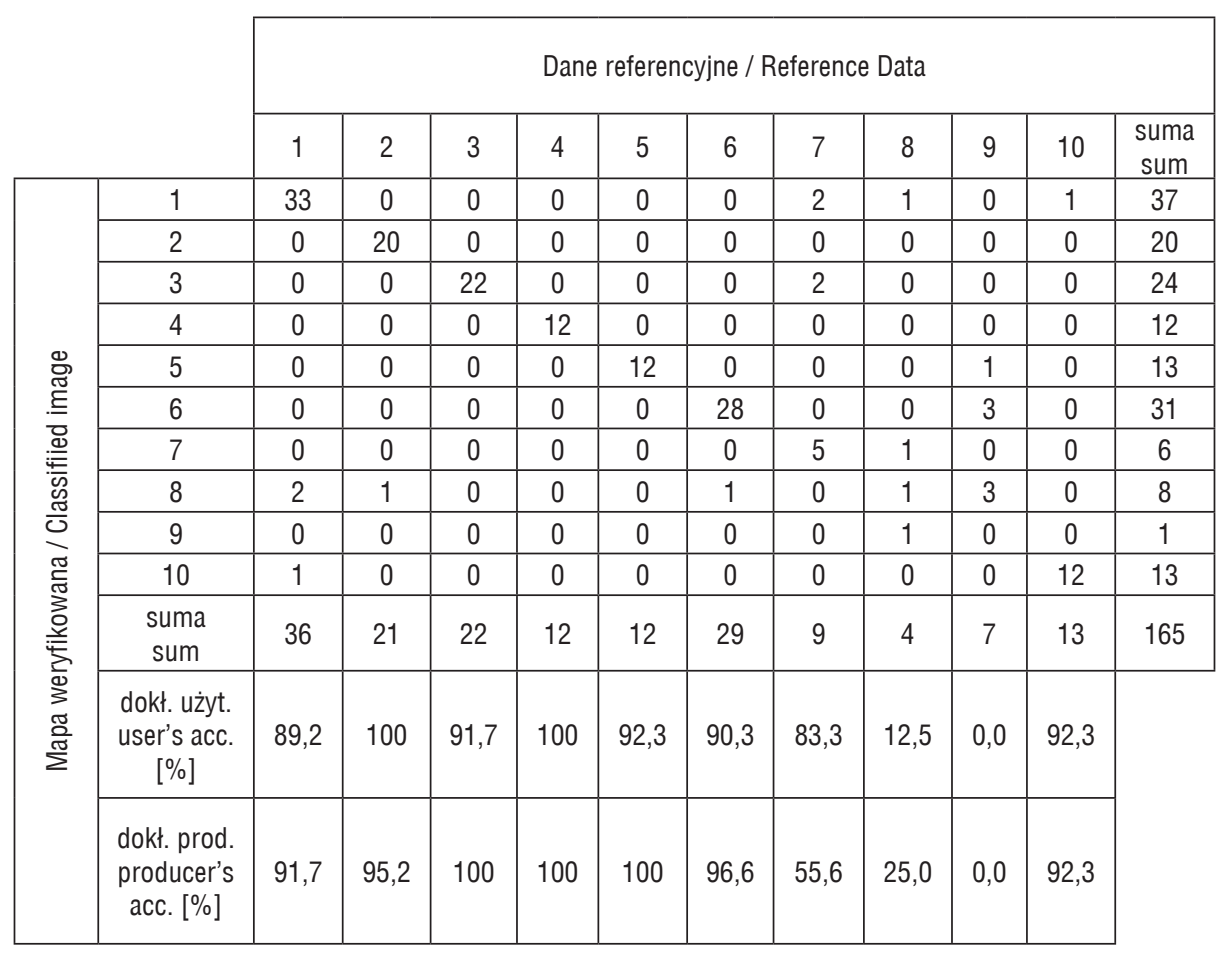

klasyfikacji metodą Random Forest okazała się wyższa od dokładności klasyfikacji metodą SVM zarówno dla różnych metod integracji, jak i polaryzacji danych radarowych. Najwyższą dokładność klasyfikacji metodą SVM uzyskano dla kombinacji IHS VV, dokładność ogólna osiągnęła jednak niecałe 70\%. W przypadku klasyfikacji metodą Random Forest najniższe wartości dokładności ogólnej osiągnięto dla integracji metodą Brovey VH oraz IHS VH, natomiast w klasyfikacji SVM najniższą dokładność uzyskano dla kombinacji Brovey VV i Brovey VH. W przypadku klasyfikacji pojedynczego, niezintegrowanego obrazu OLI w klasyfikacji metodą Random Forest ogólna dokładność wyniosła 85,7\%, a współczynnik Kappa 83,5\%. W klasyfikacji metodą SVM współczynniki dokładności wyniosły kolejno 64,6\% 
oraz 58,7\%. W przypadku klasyfikacji metodą Random Forest tylko dla kombinacji Ehlers VV uzyskano dokładniejsze wyniki, natomiast w klasyfikacji SVM dla PCA VV, PCA VH oraz IHS VV.

\section{Dyskusja}

Wykorzystanie różnych technik integracji obrazów miało znaczący wpływ na otrzymane wyniki - część algorytmów jest bowiem bardziej odpowiednia do zachowania cech przestrzennych obrazu, część do zachowania cech spektralnych. Warto zaznaczyć, że wykorzystane techniki fuzji danych satelitarnych zostały opracowane z myślą o danych optycznych - najczęściej do integracji danych multispektralnych z obrazem panchromatycznym o wyższej rozdzielczości (Hong i in. 2009). Analiza wizualna otrzymanych wyników pozwala zauważyć pewne prawidłowości. Przede wszystkim obrazy zintegrowane metodami Ehlers oraz IHS najlepiej zachowują właściwości spektralne - kolory na oryginalnym obrazie OLI oraz obrazie zintegrowanym są do siebie najbardziej zbliżone (ryc. 6). Najwyraźniejsze granice poszczególnych obiektów są widoczne na obrazach zintegrowanych metodą Ehlers oraz PCA. Analiza jakościowa (ocena wizualna) otrzymanych obrazów, pozwala stwierdzić, że najlepsze działanie przy łączeniu danych optycznych i radarowych charakteryzuje technikę Ehlers. Zintegrowane dane otrzymane z wykorzystaniem tej techniki zachowują wierność spektralną, co potwierdzają badania m.in. Klonusa (2008), Abdikana i Sanli (2012) oraz Pohl (2013). Według Klonusa (2008) metoda Ehlers w porównaniu z innymi technikami integracji charakteryzuje się najwyższymi wskaźnikami korelacji obrazów zintegrowanych z wejściowymi obrazami optycznymi. Największe zniekształcenia wartości spektralnych oraz tekstury między oryginalnym obrazem a obrazem zintegrowanym występują z kolei dla integracji metodą Brovey. Zniekształcenia wartości spektralnych występują również dla integracji metodą PCA, która powoduje wzmocnienie szczegółów przestrzennych (zachowanie granic), ale i zaburzenia cech spektralnych, co potwierdzają również badania m.in. Ulricha i in. (2007). Zachowanie charakterystyk spektralnych oraz cech przestrzennych obrazu ma istotny wpływ na późniejszą dokładność klasyfikacji zintegrowanych danych. W niniejszych badaniach najwyższe dokładności klasyfikacji upraw zostały osiągnięte przy zastosowaniu integracji metodami Ehlers oraz PCA, najniższe zaś metodą Brovey.

Po wstępnej ocenie wizualnej integracja metodami HPF oraz transformacji falkowej została odrzucona, jednakże w wielu badaniach za najlepszą technikę integracji danych optycznych i radarowych jest uznawana właśnie transformacja falkowa (Amarsaikhan i in. 2010). Z kolei w badaniach Shanmugama i in. (2005) to metoda Brovey jest najbardziej obiecującą techniką jeżeli chodzi o zachowanie informacji spektralnej, przestrzennej i teksturalnej. Może to świadczyć o tym, 


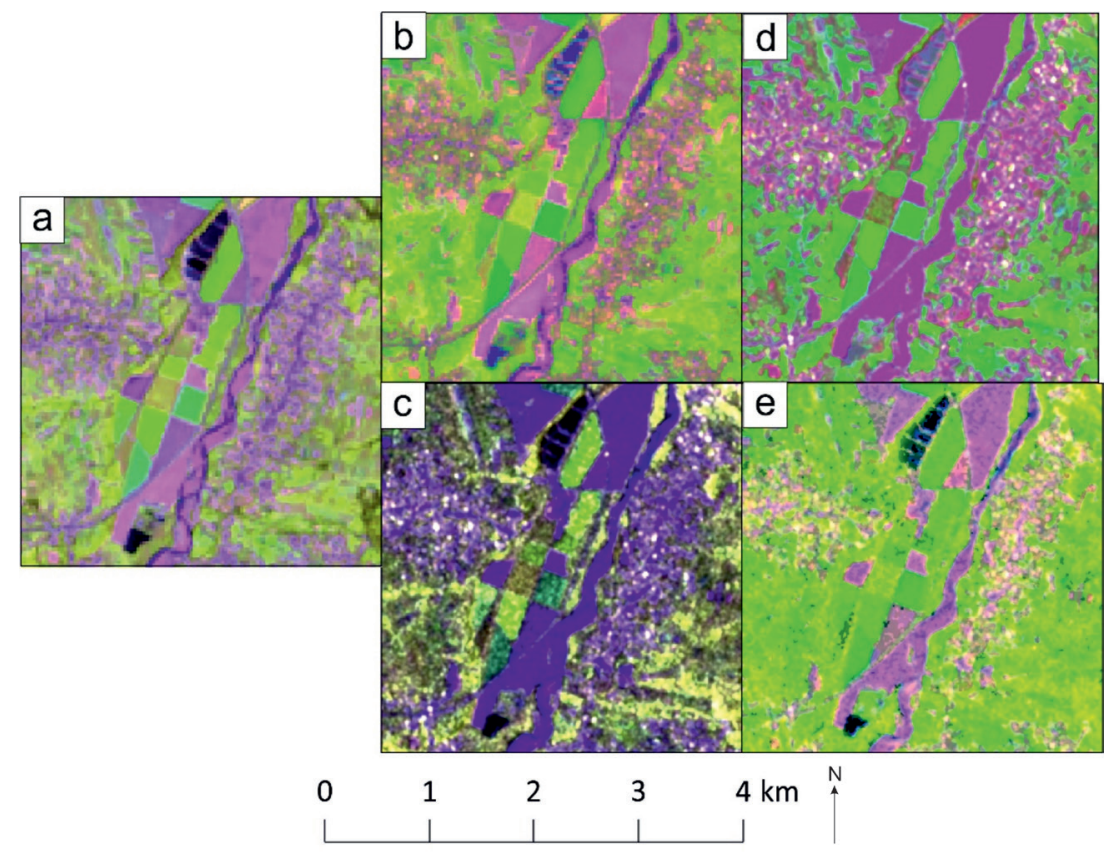

Ryc. 6. Przykład obrazów będących wynikami zastosowania różnych technik integracji danych optycznych (obraz OLI) i radarowych (dane Sentinel-1A) porównane z oryginalnym obrazem OLI: a - oryginalny obraz OLI (kompozycja kanałów: 6, 5, 4), b - integracja Ehlers, polaryzacja VV, c - Brovey, VV, d - PCA, VV, e - IHS, VV

Fig. 6. Examples of images obtained using different techniques of optical (Landsat OLI) and radar data (Sentinel-1A) integration compared with the original OLI image: a - original OLI image (band composition: 6, 5, 4), b - Ehlers, VV, c - Brovey, VV, d-PCA, VV, e - IHS, VV

że oprócz wybranej techniki integracji na otrzymane wyniki mają wpływ także inne czynniki, m.in. rodzaj użytych danych bądź też specyfika obszaru badań. Osiągnięty w pracy poziom dokładności klasyfikacji upraw jest zadowalający i porównywalny z dokładnością uzyskiwaną w podobnych pracach na terenie np. Danii (Sandholt 2001), Holandii (DeWit, Clevers 2004) i Kanady (McNairn i in. 2013; Iannini i in. 2013). W porównaniu z innymi badaniami dotyczącymi integracji danych optycznych i radarowych dokładność jest nieco niższa - dla najwyższej dokładności klasyfikacji osiągniętej w pracy $(87,9 \%)$ różnica wynosi od $2 \%$ do $9 \%$.

Zdecydowanie wyższe dokładności osiągnięto dla klasyfikacji metodą Random Forest (od 72,7\% do 87,9\%) niż metodą SVM (od 51,5\% do 69,7\%). Klasyfikacja metodą Random Forest jest dobrym wyborem w badaniach obejmujących dane 
wielowymiarowe, pochodzące z różnych źródeł. W przypadku badań dotyczących klasyfikacji typów pokrycia terenu klasyfikacja metodą Random Forest osiąga wyższe dokładności niż klasyfikacja z wykorzystaniem klasycznych drzew decyzyjnych, zarówno przy wykorzystaniu danych optycznych (Rodriguez-Galiano i in. 2012), jak i radarowych (Waske, Braun 2009). W przypadku klasyfikacji obrazów radarowych metody maksymalnego prawdopodobieństwa oraz klasyczne drzewa decyzyjne zachowują struktury klasyfikowanych obszarów, są jednakże narażone na efekt ,soli i pieprzu”, charakterystyczny przy klasyfikacji danych SAR (Waske, Braun 2009). W porównaniu z algorytmem SVM Random Forest wymaga specyfikacji mniejszej liczby parametrów, są one również łatwiejsze do zdefiniowania (Pal 2005; Rodriguez-Galiano i in. 2012). Wyniki otrzymane w klasyfikacji metodą Random Forest są bardziej stabilne niż w innych metodach, są one również bardziej obiecujące, biorąc pod uwagę poziom szczegółowości, np. różne typy upraw (Waske, Braun 2009).

W badaniach dotyczących klasyfikacji upraw przeprowadzonych przez Nitzego i in. (2012) wyższą dokładność klasyfikacji uzyskano przy użyciu algorytmu SVM niż Random Forest, badania te wykorzystywały jednak wyłącznie wysokorozdzielcze dane optyczne. W przypadku klasyfikacji danych hiperspektralnych osiągane wartości dokładności dla SVM i Random Forest są porównywalne, przy czym klasyfikacja obrazów metodą Random Forest jest znacznie szybsza (Abe 2014).

Dokładność klasyfikacji zintegrowanych danych optycznych i radarowych w większości przypadków okazała się niższa lub porównywalna z tą osiągniętą przy klasyfikacji pojedynczego obrazu OLI. W klasyfikacji metodą Random Forest najwyższa dokładność dla zintegrowanych obrazów wyniosła $87,9 \%$, podczas gdy dla obrazu OLI - 85,7\%. Także w badaniach McNairna i in. (2009) dokładność klasyfikacji została nieznacznie poprawiona przy zastosowaniu kombinacji obrazów optycznych i radarowych w stosunku do samych danych optycznych. Wykorzystanie w integracji tylko jednego obrazu radarowego może być bowiem niewystarczające do osiągnięcia znaczącej poprawy dokładności. Niestety z racji niedostępności danych wykorzystanie większej liczby obrazów, a tym samym odpowiedź na pytanie, jak użycie danych z różnych momentów czasowych pozwala zwiększyć dokładność, było niemożliwe. Warto przypomnieć, że dwa klasyfikowane obrazy pochodziły z dość odległych momentów czasowych (różnica dwóch miesięcy). Przy czym obraz radarowy został pozyskany w sierpniu, a więc w porze żniw niektórych z analizowanych upraw. Optymalne byłoby więc zastąpienie bądź dodatkowe wykorzystanie obrazu radarowego pozyskanego dla wcześniejszego momentu czasowego, np. z lipca. $Z$ dotychczasowych badań wynika (np. De Wit, Clevers 2004; Blaes i in. 2005; Iannini i in. 2013), że wybór optymalnych momentów czasowych z okresu wegetacyjnego, dla których pozyskiwane są obrazy, jest niezwykle istotny w osiągnięciu wysokiej dokładności klasyfikacji upraw. Jest to wręcz kluczowy element i warunek teledetekcyjnych badań upraw, przy czym ze 
względu na często ograniczony dostęp do danych jest to warunek trudny do spełnienia. Niestety w przeprowadzonych badaniach nie było możliwe wykorzystanie danych dla innych momentów czasowych - dla danych optycznych z racji zachmurzenia obszaru, natomiast w przypadku danych radarowych dane były dostępne od października 2014 r. Mimo wykorzystania tylko dwóch obrazów osiągnięta dokładność jest jednak satysfakcjonująca.

\section{Wnioski}

Wykorzystanie zintegrowanych danych optycznych i radarowych w klasyfikacji upraw pozwala na osiągnięcie wysokiej dokładności opracowanych map, jest jednak silnie zależne od zastosowanej metody integracji oraz algorytmu klasyfikacyjnego. Najwyższa osiągnięta dokładność ogólna osiągnęła 87,9\%. Polecanymi metodami integracji danych optycznych i radarowych w identyfikacji upraw są techniki Ehlers i PCA oraz klasyfikacja metodą Random Forest. Warto pamiętać, że na osiągniętą dokładność, oprócz wybranych algorytmów przetworzeń, ma wpływ szereg innych czynników: dobór danych, specyfika obszaru - uprawiane rośliny, a także rozdrobnienie gospodarstw i pól uprawnych. Niezwykle istotne jest również wykorzystanie danych dla kilku różnych momentów czasowych dla okresu wegetacyjnego na badanym obszarze, które w tym opracowaniu było niemożliwe. W przypadku danych satelitarnych o rozdzielczości 30- i 10-metrowej, użytych w tych badaniach, wynik klasyfikacji upraw często może nie być satysfakcjonujący. Warto również zaznaczyć, że wykorzystane dane są stosunkowo nowe, dlatego zapewne potrzebne są dalsze badania, dotyczące m.in. opracowania metod ich przetworzeń.

\section{Literatura}

Abdikan S., Sanli F.B., 2012, Comparison of different fusion algorithms in urban and agricultural areas using SAR (PALSAR and RADARSAT) and optical (SPOT) images, Boletim de Ciências Geodésicas, 18 (4), 509-531.

Abe B.T., Olugbara O.O., Marwala T., 2014, Experimental comparison of support vector machines with random forests for hyperspectral image land cover classification, Journal of Earth System Science, 123 (4), 779-790.

Amarsaikhan D., Blotevogel H.H., Van Genderen J.L., Ganzorig M., Gantuya R., Nergui B., 2010, Fusing high-resolution SAR and optical imagery for improved urban land cover study and classification, International Journal of Image and Data Fusion, 1 (1), 83-97.

Balon J., German K., Kozak J., Malara H., Widacki W., Ziaja W., 1995, Regiony fizycznogeograficzne, [w:] J. Warszyńska (red.), Karpaty Polskie, Uniwersytet Jagielloński, Kraków, $117-130$. 
Ban Y., 1996, Multi-temporal ERS-1 SAR and Landsat TM data for agricultural crop classification: An artificial neural network approach, International Archives of Photogrammetry and Remote Sensing, XXXI (B7), 48-52.

Ban Y., Gong P., Giri C., 2015, Global land cover mapping using Earth observation satellite data: Recent progresses and challenges, ISPRS Journal of Photogrammetry and Remote Sensing, 103, 1-6.

Blaes X., Vanhalle L., Defourney P., 2005, Efficiency of crop identification based on optical and SAR image time series, Remote Sensing of Environment, 96, 352-356.

Bochenek Z., Ciołkosz A., Filipiak K., 2000, Szacowanie powierzchni upraw z wykorzystaniem teledetekcji lotniczej i satelitarnej, Fotointerpretacja w Geografii, 31, 129-136.

Cortes C., Vapnik V., 1995, Support-Vector Networks, Machine Learning, 20, 273-297.

De Wit A.J.W., Clevers J.G.P.W., 2004, Efficiency and accuracy of per-field classification for operational crop mapping, International Journal of Remote Sensing, 25 (20), 4091-4112.

Doraiswamy P., Moulin S., Cook P.W., Stern A., 2003, Crop Yield Assessment from Remote Sensing, Photogrammetric Engineering \& Remote Sensing, 69 (6), 665-674.

Forkuor G., Conrad C., Thiel M., Ullmann T., Zoungrana E., 2014, Integration of Optical and Synthetic Aperture Radar Imagery for Improving Crop Mapping in Northwestern Benin, West Africa, Remote Sensing, 6, 6472-6499.

Hong G., Zhang Y., Mercer B., 2009, A wavelet and IHS integration method to fuse high resolution SAR with moderate resolution multispectral images, Photogrammetric Engineering \& Remote Sensing, 75 (10), 1213-1223.

Horning N., 2010, Random Forests: An algorithm for image classification and generation of continuous fields data sets, International Conference on Geoinformatics for Spatial Infrastructure Development in Earth and Allied Sciences, Hanoi, Vietnam.

Huang C., Davis L.S., Townshend J.R.G., 2002, An assessment of support vector machines for land cover classification, International Journal of Remote Sensing, 23 (4), 725-749.

Iannini L., Molijna R.A., Hanssena R.F., 2013, Integration of Multispectral and C-Band SAR Data for Crop Classification, Remote Sensing for Agriculture, Ecosystems, and Hydrology XV.

Jain M., Mondal P., DeFries R.S., Small C., Galford G.L., 2013, Mapping cropping intensity of smallholder farms: A comparison of methods using multiple sensors, Remote Sensing of Environment, 134, 210-223.

Jewell N., 1989, An evaluation of multi-date SPOT data for agriculture and land use mapping in the United Kingdom, International Journal of Remote Sensing, 10 (6), 939-951.

Joshi N., Baumann M., Ehammer A., Fensholt R., Grogan K., Hostert P., Jepsen M.R., Kuemmerle T., Meyfroidt P., Mitchard E.T.A., Reiche J., Ryan C.M., Waske B., 2016, A Review of the Application of Optical and Radar Remote Sensing Data Fusion to Land Use Mapping and Monitoring, Remote Sensing, 70 (8), 1-23.

Klonus S., 2008, Comparison of pansharpening algorithms for combining radar and multispectral data, The International Archives of the Photogrammetry, Remote Sensing and Spatial Information Sciences, XXXVII, B6b. 
Klonus S., Ehlers M., 2009, Performance of evaluation methods in image fusion, $12^{\text {th }}$ International Conference on Information Fusion, 1409-1416.

Kondracki J., 1998, Geografia regionalna Polski, Wydawnictwo Naukowe PWN, Warszawa.

Leśniak B., Obrębska-Starklowa B., 1983, Klimat województwa bielskiego, Folia Geographica, Ser. Geogr.-Phys., XV, 21-49.

Liu M.W., 2011, Crop type classification using satellite images of different resolutions, $\mathrm{PhD}$ Thesis, University of Wisconsin.

Maiersperger T.K., Scaramuzza P.L., Leigh L., Shrestha S., Gallo K.P., Jenkerson C.B., Dwyer J.L 2013, Characterizing LEDAPS surface reflectance products by comparisons with AERONET, field spectrometer, and MODIS data, Remote Sensing of Environment, 136, 1-13.

McNairn H., Champagne C., Shang J., Holmstrom D., Reichert G., 2009, Integration of optical and Synthetic Aperture Radar (SAR) imagery for delivering operational annual crop inventories, ISPRSS Journal of Photogrammetry and Remote Sensing, 64, 434-449.

Moran S.M., Hymer D.C., Qi J., Kerr Y., 2002, Comparison of ERS-2 SAR and Landsat TM imagery for monitoring agricultural crop and soil conditions, Remote Sensing of Environment, 79, 243-252.

Murakami T., Ogawa S., Ishitsuka N., Kumagai K., Saito G., 2001, Crop discrimination with multitemporal SPOT/HRV data in the Saga Plains, Japan, International Journal of Remote Sensing, 22, 1335-1348.

Nitze I., Schulthess U., Asche H., 2012, Comparison of Machine Learning Algorithms Random Forest, Artificial Neural Network and Support Vector Machine to Maximum Likelihood for Supervised Crop Type Classification, Proceedings of the $4^{\text {th }}$ GEOBIA, 035-040.

Obrębska-Starklowa B., Hess M., Olecki Z., Trepińska J., Kowanetz L., 1995, Klimat, [w:] J. Warszyńska (red.), Karpaty Polskie, Uniwersytet Jagielloński, Kraków, 31-47.

Pal M., 2005, Random forest classifier for remote sensing classification, International Journal of Remote Sensing, 26 (1), 217-222.

Pohl C., Van Genderen J.L., 1998, Multisensor image fusion in remote sensing: concepts, methods and applications, International Journal of Remote Sensing, 19 (5), 823-854.

Pohl C., 2013, Challenges of remote sensing image fusion to optimize earth observation data exploitation, European Scientific Journal December, 4, 355-365.

Rodriguez-Galiano V.F., Ghimire B., Rogan J., Chica-Olmo M., Rigol-Sanchez J.P., 2012, An assessment of the effectiveness of a random forest classifier for land-cover classification, ISPRS Journal of Photogrammetry and Remote Sensing, 67, 93-104.

Rosenthal W.D., Blanchard B., 1984, Active microwave responses: An aid in improved crop classification, Photogrammetric Engineering and Remote Sensing, 50 (4), 461-468.

Roy D.P., Wulder M.A., Loveland T.R., Woodcock, C.E., Allen R.G., Anderson M.C., Helder D., Irons J.R., Johnson D.M., Kenney R., Scambos T.A., Schaaf C.B., Schott J.R., Sheng Y., Vermote E.F., Belward A.S., Bindschadler R., Cohen W.B., Gao F., Hipple J.D., Hostert P., Huntington J., Justice C.O., Kilic A., Kovalskyy V., Lee Z.P., Lymburner L., Masek J.G., McCorkel J., Shuai Y., Trezza R., Vogelmann J., Wynne R.H., Zhu Z., 2014, Landsat-8: 
Science and product vision for terrestrial global change research, Remote Sensing of Environment, 145, 154-172.

Sandholt I., 2001, The combination of polarimetric SAR with satellite SAR and optical data for classification of agricultural land, Danish Journal of Geography, 101, 21-32.

Sarup J., Singhai A., 2011, Image fusion techniques for accurate classification of Remote Sensing data, International Journal Of Geomatics And Geosciences, 2 (2), 602-612.

Schotten C.G.J., Van Rooy W.W.L., Janssen L.L.F., 1995, Assessment of the capabilities of multitemporal ERS-l SAR data to discriminate between agricultural crops, International Journal of Remote Sensing, 16 (14), 2619-2637.

Sentinel-1 Product Definition, 2011, MacDonald, Dettwiler and Associates Ltd., Richmond, B.C., Canada.

Shanmugam P., Manjunath A.S., Ahn Y.H., Sanjeevi S., Ryul J.H., 2005, Application of Multisensor Fusion Techniques in Remote Sensing of Coastal Mangrove Wetlands, International Journal of Geoinformatics, 1 (3), 1-17.

Skiba S., 1995, Pokrywa glebowa, [w:] J. Warszyńska (red.), Karpaty Polskie, Uniwersytet Jagielloński, Kraków, 69-76.

Tso B., Mather P.M., 1999, Crop discrimination using multi-temporal SAR imagery, International Journal of Remote Sensing, 20 (12), 2443-2460.

Turker M., Arikan M., 2005, Sequential masking classification of multi-temporal Landsat ETM+ images for field-based crop mapping in Karacabey, Turkey, International Journal of Remote Sensing, 26 (17), 3813-3830.

Ulrich M., Klonus S., Ehlers M., Astrand P.J., 2007, Image fusion of multitemporal and multisensoral data, GeoInformation in Europe, 257-266.

Wang X., Ge L., Li X., 2012, Evaluation of filters for ENVISAT ASAR speckle suppression in pasture area, ISPRS Annals of the Photogrammetry, Remote Sensing and Spatial Information Sciences, I-7, 341-346.

Warner T.A., Nellis M.D., Foody G.M., 2009, The Sage Handbook of Remote Sensing, Sage Publications Inc.

Waske B., Braun M., 2009, Classifier ensembles for land cover mapping using multitemporal SAR imagery, ISPRS Journal of Photogrammetry and Remote Sensing, 64, 450-457.

Yan L., Roy D.P., 2014, Automated crop field extraction from multi-temporal Web Enabled Landsat Data, Remote Sensing of Environment, 144, 42-64.

Bank Danych Lokalnych GUS, http://stat.gov.pl/ (styczeń 2016).

EarthExplorer, http://earthexplorer.usgs.gov/ (styczeń 2016).

EnMAP, http://www.enmap.org (styczeń 2016).

Ewa Grabska

Uniwersytet Jagielloński wKrakowie

Instytut Geografii i Gospodarki Præestræennej

ul. Gronostajowa 7, 30-387 Krakow

egrabska@gis.geo.uj.edu.pl 
